\title{
STUDY OF THE STRENGTH CHARACTERISTICS OF PROTEIN-BASED LIGHTWEIGHT FOAMED CONCRETE WITH CEMENT PARTIALLY REPLACED WITH RICE HUSK ASH
}

\author{
E. B Coker ${ }^{1,}{ }^{*}$, S. Sadiku2 ${ }^{2}$ J. I. Aguwa ${ }^{3}$ and M. Abdullahi ${ }^{4}$ \\ 1, Satellite Towns DeVelopment Department, Fed Capital Territory ADMINISTRATION, Abuja, NigERIA. \\ 2,3,4 Department of Civil Engineering, Federal University of Technology, Minna, Niger State. Nigeria. \\ E-mail addresses:1bunmicoker@gmail.com,2profssadikov@gmail.com,3jiaguwa@gmail.com, \\ 4abdulapai@yahoo.com
}

\begin{abstract}
Compressive strength test was carried out on the protein-based lightweight foamed concrete produced with cement partially replaced by rice husk ash to ascertain its strength characteristics. Standard concrete cubes of $150 \times 150 \mathrm{x}$ $150 \mathrm{~mm}$ were produced using ordinary Portland cement (OPC), fine aggregate, aqueous protein-based foaming agent and rice husk ash (RHA). The RHA was used to replace cement at $5 \%, 10 \%, 15 \%, 20 \%, 25 \%, 30 \%, 35 \%, 40$ $\%, 45 \%$ and $50 \%$ by weight of cement. Control cubes with no cement replacement ( $0 \%)$, were also produced and used as reference points for comparing the compressive strength of the lightweight foamed concrete at 28 days and 56 days respectively. The mix proportion of 1:1.5 was used as binder/fine aggregate proportions with the foam occupying $20 \%$ of the volume of the concrete and the other constituents occupying the remaining $80 \%$. The compressive strengths of the lightweight foamed concrete at both 28 days and 56 days, increased for cement replacement levels of $5-30 \%$ and gradually decreased for cement replacement levels of $35-50 \%$ respectively for the mix proportion of 1:1.5 and for the water/binder ratio of 0.4. The minimum 28 days compressive strength for the mix proportion of 1:1.5 at cement replacement level of $30 \%$ and water/binder ratio of 0.4 was 15.52 $\mathrm{N} / \mathrm{mm}^{2}$ while that at 56 days was $18.51 \mathrm{~N} / \mathrm{mm}^{2}$. The rice husk ash is a pozzolanic material with a capability of contributing up to $80 \%$ and above to the compressive strength of lightweight foamed concrete, if the percentage replacement does not exceed $30 \%$. The mix proportion of 1:1.5 at water/binder ratio of 0.4 produces a structural lightweight concrete at 28 days.
\end{abstract}

Key words: Compressive Strength, Lightweight Foamed Concrete, Ordinary Portland Cement, Protein-based Foaming Agent, Rice Husk Ash.

\section{INTRODUCTION}

Lightweight foamed concrete (LFC) is defined as a lightweight material having a minimum of $20 \%$ (by volume) of mechanically entrained foam in the plastic mortar [1]. Lightweight foamed concrete is concrete, which in its most basic form consists of sand, cement, water and voids. The voids are usually introduced into the system by separately adding the foaming agent to the water at the required mix ratio in a foam generator to produce manufactured foam. This foam is then injected into the cement slurry and allowed to mix and blend properly to create a foamed slurry. Lightweight foamed concrete has a surprisingly long history, which was first patented in 1924, mainly for use as an insulation material. The application of lightweight foamed concrete for construction works was not recognised until the late 1970s, when it began to be used in the Netherlands for filling voids and for ground engineering applications [2]. Significant improvements in production methods and the quality of foaming agents over the last 15 years, have led to increased production and broadening of the range of applications of lightweight foamed concrete [3].

Foaming agents, are compounds or air entraining agents known to lower the surface tension of a liquid, thus allowing easier spreading and lowering of the interfacial tension between two liquids, or between a liquid and a solid. There are two basic types of 
foaming agent namely synthetic and protein-based. Synthetic foaming agents have a density of 40 $\mathrm{kg} / \mathrm{m}^{3}$ and are purely chemical products, while protein-based foaming agents have a density of 80 $\mathrm{kg} / \mathrm{m}^{3}$ and are derived from animal protein byproducts such as horn, blood, bones of cows, pigs and other remainders of animal carcasses that have been hydrolysed and chemically modified to improve the physical properties of the foam mortar like reduced surface tension, increased foaming ability and foam stability [4].

Rice husk is an agro-waste product of agricultural industry constituting one-fifth (20\%) by weight when the rice is milled and this is a significant amount considering the over 100 million tonnes of rice husk produced every year worldwide out of which about 90 $\%$ of this amount is from developing countries [5]. When rice husk is combusted, it produces ash known as rice husk ash, which is very rich in silica. This silica combines with the liberated lime during the hydration of cement in a reaction known as pozzolanic reaction, to form a gel-like compound, calcium silicate hydrate (C-S-H), which is responsible for the further strength development of the lightweight foamed concrete.

There are several steps involved in the pozzolanic reaction in concrete. As Portland cement reacts with water, the tricalcium silicate $\left(\mathrm{C}_{3} \mathrm{~S}\right)$ and dicalcium silicates $\left(\mathrm{C}_{2} \mathrm{~S}\right)$ react to form calcium silicate hydrates (C-S-H), which is largely responsible for the strength development, together with calcium hydroxide, $\mathrm{Ca}(\mathrm{OH})_{2}$, often referred to as hydrated lime as presented by:

$2 \mathrm{Ca}_{3} \mathrm{SiO}_{\mathrm{s}}+7 \mathrm{H}_{2} \mathrm{O}$

$$
\rightarrow 3 \mathrm{CaO} .2 \mathrm{SiO}_{2} \cdot 4 \mathrm{H}_{2} \mathrm{O}+3 \mathrm{Ca}(\mathrm{OH})_{2}(1)
$$

At the same time, the $\mathrm{pH}$ which is the measure of alkalinity of the water, now referred to as pore fluid, increases from 9 to 13 or higher. This combination of events provides ideal conditions under which the pozzolana can react. According to [6], the high $\mathrm{pH}$ first causes the silicate network structure of the pozzolana to break down to smaller units, which then react with the calcium hydroxide to form more calcium silicate hydrate (C-S-H) binder. The net effect is that the calcium hydroxide in the concrete, which itself has no strength-forming properties rather present a potential source of weakness for certain forms of chemical degradation, is converted by the pozzolana to additional C-S-H binder (see eq. (2)) that is deposited in the pore spaces.

$3 \mathrm{Ca}(\mathrm{OH})_{2}+2 \mathrm{SiO}_{2}+\mathrm{H}_{2} \mathrm{O}$

$$
\rightarrow 3 \mathrm{CaO} .2 \mathrm{SiO}_{2} \cdot 4 \mathrm{H}_{2} \mathrm{O}
$$

All these reactions lead to a general densification of the cement matrix, which contributes to increased strength, reduced permeability and increased longterm durability [6].

Lightweight foamed mortar does not require compaction. It flows readily from a pump outlet to fill restricted and irregular cavities. It can also be pumped successfully over significant heights and distances. The 28 days compressive strength of the material varies according to its constituents, largely its air voids content, but usually from 1 to $25 \mathrm{~N} / \mathrm{mm}^{2}$ [7].

The aim of this study is to study the strength characteristics of lightweight foamed concrete with cement partially replaced with rice husk ash. The objectives are to carry out experiments on the lightweight foamed concrete with a view to determining the compressive strength of the concrete as the percentage of partial replacement of cement increases, to compare the compressive strength of the control concrete with that in which cement was partially replaced with rice husk ash, to study the feasibility of rice husk ash as a good and viable partial replacement for cement and to evaluate the suitability of using locally available materials of protein and rice husk ash for the production of lightweight concrete.

\section{MATERIALS}

The fine aggregate was sourced from the Sabondaga riverbed in Minna, Niger State, Nigeria, ordinary Portland cement was bought within Minna Municipality, Clean Water was obtained from the borehole within the Gidan Kwano area of Minna, the Rice Husk was sourced from Rice Mills in Bida, Niger State and the Protein-based Foaming Agent was bought from the producer in Lagos, Nigeria.

\subsection{Method}

The rice husk ash was produced by controlled calcination in a locally fabricated kiln at a temperature of $660{ }^{\circ} \mathrm{C}$ when the $\mathrm{SiO}_{2}$ was still in amorphous phase. The X-ray Diffraction and X-ray Fluorescence analyses were used to determine the silica phase and the chemical composition of the RHA and the cement respectively. Blaine's Fineness method was used to determine the specific surface area of the RHA and cement in accordance with [8]. Mix proportions of binder/sand ratio of 1:1.5 was used with the water/binder ratio of 0.4 . This quantity of water was required to wet the high surface area of the particles of the OPC and RHA and facilitate workability of the concrete. The foaming agent/water dilution ratio was 1:20. The mechanically entrained foam occupied 
$20 \%$ by volume in $1 \mathrm{~m}^{3}$ of the plastic concrete in accordance with the requirements contained in [1] while the other constituents, sand, cement, rice husk ash and water occupied the remaining $80 \%$. All the constituent materials including water were proportioned by weight and properly mixed until a very uniform, consistent and well blended mixture was obtained. The foam from the pre-mixed Segun Ilori Engineering Limited (SIEL) foaming agent was prepared in a SIEL Premium Mini Foam Generator and the specified quantity of foam was injected into the wet mix while mixing the other components of the mixtures, blended together until a homogenous mixture was achieved. The concrete cube samples were cast and demoulded after 24 hours, cured in water at ambient temperature of $25^{\circ} \mathrm{C}$ for 28 days and 56 days respectively before testing for compressive strength.

\subsection{Mix Constituents}

The basic mix proportions for the concrete constituents and the amount of foam added were calculated using the following equations developed by [9], which is based on Absolute Volume Method:

$$
\begin{aligned}
\rho_{m}=C+C( & (w / c)+C(a / c)+C(s / c) \\
& +C(a / c)(w / a)+C(s / c)(w / s) \\
& +S \cdot G f \times V f \\
1=\frac{C}{S \cdot G_{c}}+C & \frac{(w / c)}{S \cdot G_{w}}+C \frac{(a / c)}{S \cdot G_{r h a}}+C \frac{(s / c)}{S \cdot G_{s}} \\
& +C(a / c)(w / a)+C(s / c)(w / s) \\
& +V f
\end{aligned}
$$

Eq. 3 is in $\mathrm{kg} / \mathrm{m}^{3}$ while eq. 4 is in $\mathrm{m}^{3}$. Equation (4) is the absolute volume method relating the ratios of the various constituents, their specific gravities and the cement quantity C. In these equations, $\rho_{\mathrm{m}}$ is the Target Casting Density (TCD) in $\mathrm{kg} / \mathrm{m}^{3} ; \mathrm{w} / \mathrm{c}$ is water/cement ratio $=0.4 ; \mathrm{C}$ is the Cement Content $\left(\mathrm{kg}\right.$ per $\left.^{3}\right) ; \mathrm{V}_{\mathrm{f}}$ is the volume of foam $=20 \% ; \mathrm{a} / \mathrm{c}=\mathrm{ash} /$ cement ratio $=$
$0,5 \%, 10 \%, 15 \%, 20 \%, 25 \%, 30 \%, 35 \%, 40 \%, 45 \%$, $50 \% ; \mathrm{s} / \mathrm{c}$ is the sand/cement ratio $=1: 1.5 ; \mathrm{w} / \mathrm{a}$ is the water/ash ratio; S.G $G_{f}$ is the specific gravity of foam; S.G $G_{c}$ is the specific gravity of cement $=3.15$; $S$. $G_{\text {rha }}$ is the specific gravity of RHA $=2.05$; S. $_{\text {s }}$ is the specific gravity of sand $=2.66$ and $S . G_{w}$ is the specific gravity of water $=1.00$.

The mix ratio of 1:1.5 (binder: fine aggregates) was used. The specific gravities of sand, RHA and cement as determined in the laboratory, were given as 2.66 , 2.05 and 3.15 respectively. These values were substituted into (3) and (4) respectively, and the ratios of the constituent materials, that is, $\mathrm{w} / \mathrm{c}, \mathrm{fa} / \mathrm{c}$ (or c/fa), ash/c, w/ash and $\mathrm{w} / \mathrm{fa}$ ratios were calculated and tabulated as shown in Table 1.

\subsection{Mix Constituents for Lightweight Foamed Concrete.}

Table 1 shows the replacement of cement by rice husk ash up from $0-50 \%$ and the weights of the individual material within this percent cement replacement. The calculated weight of OPC represents the weight of the cement required for $1 \mathrm{~m}^{3}$ of concrete while the weight of the OPC, represents the weight of cement used to prepare a cube of concrete and 8.10 litres represents the $20 \%$ of the total volume of concrete occupied by the foam, which was kept constant. The ratios of the constituent materials, that is, w/c, fa/c (or c/fa), ash/c, w/ash and w/fa ratios can also be observed in Table 1. The foam was injected into the concrete from the foam generator while mixing was ongoing.

\subsection{Curing}

Curing condition is very important in the ability of

\begin{tabular}{|c|c|c|c|c|c|c|c|c|c|c|c|c|}
\hline $\begin{array}{l}\text { Target } \\
\text { Casting } \\
\text { Density } \\
\left(\mathrm{kg} / \mathrm{m}^{3}\right)\end{array}$ & $\begin{array}{l}\text { Calculated } \\
\text { Weight of } \\
\text { OPC }(\mathrm{kg})\end{array}$ & $\begin{array}{c}\text { Percentage } \\
\text { Replacement } \\
(\%)\end{array}$ & $\begin{array}{l}\text { Weight of } \\
\text { OPC }(k g)\end{array}$ & $\begin{array}{c}\text { Weight o } \\
\text { fa. (kg) }\end{array}$ & $\begin{array}{l}\text { Weight } \\
\text { of } \\
\text { RHA } \\
(\mathrm{kg})\end{array}$ & $\begin{array}{l}\text { Weight } \\
\text { of Water } \\
(\mathrm{kg})\end{array}$ & $\begin{array}{l}\text { Volume of } \\
\text { Foam } \\
\text { (litres) }\end{array}$ & $\begin{array}{l}\text { w/c } \\
\text { Ratio }\end{array}$ & $\begin{array}{l}\text { fa/c } \\
\text { Ratio }\end{array}$ & ash/cRatio & $\begin{array}{l}\text { w/ash } \\
\text { Ratio }\end{array}$ & $\begin{array}{l}\text { w/fa } \\
\text { Ratio }\end{array}$ \\
\hline $1,964.31$ & 595.24 & 0 & 24.11 & 36.16 & 0.00 & 9.64 & \multirow{2}{*}{8.10} & \multirow{2}{*}{0.40} & \multirow{2}{*}{1.50} & 0.00 & 0.00 & \multirow{2}{*}{0.27} \\
\hline $1,772.85$ & 475.29 & 5 & 18.29 & 27.43 & 0.96 & 7.31 & & & & 0.05 & 7.60 & \\
\hline $1,766.09$ & 469.70 & 10 & 17.12 & 25.68 & 1.90 & 6.85 & \multirow{2}{*}{8.10} & \multirow{2}{*}{0.40} & \multirow{2}{*}{1.50} & 0.10 & 3.60 & \multirow{2}{*}{0.27} \\
\hline $1,760.36$ & 464.47 & 15 & 15.99 & 23.98 & 2.82 & 6.40 & & & & 0.15 & 2.27 & \\
\hline $1,753.93$ & 459.14 & 20 & 14.88 & 22.31 & 3.72 & 5.95 & \multirow{2}{*}{8.10} & \multirow{2}{*}{0.40} & \multirow{2}{*}{1.50} & 0.20 & 1.60 & \multirow{2}{*}{0.27} \\
\hline $1,748.42$ & 454.13 & 25 & 13.79 & 20.69 & 4.60 & 5.52 & & & & 0.25 & 1.20 & \\
\hline $1,743.07$ & 449.24 & 30 & 12.74 & 19.10 & 5.46 & 5.09 & \multirow{2}{*}{8.10} & \multirow{2}{*}{0.40} & \multirow{2}{*}{1.50} & 0.30 & 0.93 & \multirow{2}{*}{0.27} \\
\hline $1,737.03$ & 444.25 & 35 & 11.69 & 17.54 & 6.30 & 4.68 & & & & 0.35 & 0.74 & \\
\hline $1,731.88$ & 439.56 & 40 & 10.68 & 16.02 & 7.12 & 4.27 & \multirow{2}{*}{8.10} & \multirow{2}{*}{0.40} & \multirow{2}{*}{1.50} & 0.40 & 0.60 & \multirow{2}{*}{0.27} \\
\hline $1,726.09$ & 434.78 & 45 & 9.68 & 14.53 & 7.92 & 3.87 & & & & 0.45 & 0.49 & \\
\hline $1,721.18$ & 430.29 & 50 & 8.71 & 13.07 & 8.71 & 3.49 & 8.10 & 0.40 & 1.50 & 0.50 & 0.40 & 0.27 \\
\hline
\end{tabular}
concrete to gain strength and the lightweight foamed concrete cube specimens were cured by total immersion in water for 28 days and 56 days respectively after demoulding them.

Table 1: Mix Constituents for Lightweight Foamed Concrete Mixes Investigated 
It is a known fact that concrete strength increases with age and faster when immersed in water than when not cured, the RHA only increases the strength or retards it depending on the replacement percentage; RHA is not a plasticizer that contributes to the rapid hardening of concrete within 28 days.

\subsection{Compressive Strength Test}

The compressive strength of the concrete cubes was done in accordance with [10], using a 2,000 kN capacity Electronic Equipment (ELE) Compressive Strength Crushing Measuring Machine. The test was carried out on the $150 \mathrm{~mm}$ cube specimens at age 28 and 56 days respectively.

\section{RESULTS AND DISCUSSION}

\subsection{Chemical Compositions of RHA and OPC}

The results of the X-ray Diffraction (XRD) and X-ray Fluorescence (XRF) analyses carried out on the rice husk ash and cement are as shown in Table 2.

It can be observed from Table 2 that the content of the $\mathrm{SiO}_{2}$ in the RHA is $86.99 \%$ with $0.69 \%$ of Potasium Oxide $\left(\mathrm{K}_{2} \mathrm{O}\right)$ and some minor amounts of other oxides. The total percentage composition of $\mathrm{SiO}_{2}$ is $86.99 \%$, $\mathrm{Al}_{2} \mathrm{O}_{3}$ is $2.55 \%, \mathrm{Fe}_{2} \mathrm{O}_{3}$ is $0.34 \%$ totaling $89.88 \%$. The value of $89.88 \%$ satisfies the minimum value of $70 \%$ specified for pozzolanas by [11]. The values of percentage composition obtained are the likely consequences of the method of preparing the ash. The values obtained for the loss on ignition (LOI) and $\mathrm{SO}_{3}$ are $0.61 \%$ and $1.45 \%$ respectively. These values also satisfy the specifications of a maximum of $6 \%$ for the LOI and $3 \%$ for $\mathrm{SO}_{3}$ by [11], thus, making the RHA a Class $\mathrm{N}$ pozzolana.

\subsection{Physical Analysis of RHA and OPC}

The results of the mean particle size and specific surface area tests carried out on the rice husk ash and cement are as shown in Table 3. Blaine's Fineness Method based on the guidelines and specifications of [8] was used to carry out the tests. Generally, calcining rice husk at a temperature below $700{ }^{\circ} \mathrm{C}$ produces amorphous crystals of rice husk ash. The rice husk used was calcined at $660{ }^{\circ} \mathrm{C}$ for 60 minutes and this produced the optimum combination of temperature and time, resulting in non-crystallised RHA. According to the x-ray diffraction profile shown in Figure 1. The specific surface areas of both RHA and cement are very important because they play a very significant role in the pozzolanic reaction during the hydration of cement and are the specific surface areas available for hydration as stipulated in [8]. According to the observation of [12], when RHA has a small particle size of less than $10 \mu \mathrm{m}$, a specific surface area range of $100-200 \mathrm{~m}^{2} / \mathrm{g}$ and most importantly, a high amorphous $\mathrm{SiO}_{2}$ content within the range of 80 - $90 \%$ by weight, then the RHA will exhibit a very good pozzolanic activity.

According to [13], the increase in the hydration heat of cement blended with rice husk ash is due to the acceleration of the early hydration of tricalcium silicate $\left(\mathrm{C}_{3} \mathrm{~S}\right)$, which is ascribed to the high specific surface area of the RHA and pozzolanic reaction.

\subsection{Profile of RHA}

Figure 1 shows the $\mathrm{x}$-ray diffraction profile after the rice husk ash was analysed by $X^{\prime}$ Pert PRO Multipurpose Diffractometer (MPD) Machine with PW 3050/60 Standard Resolution Goniometer. The figure reveals that the ash was mainly in amorphous form with evidence of amorphous phases of $\mathrm{SiO}_{2}$, with the intensity peak of 156.20 occurring around angle $22^{\circ}$ along position 2 Theta. The profile of the X-ray diffraction of the RHA shows some distinct peak height values of about 238.30, 904.00, 123.90 and 112.50 at angles of $20.82^{\circ}, 26.63^{\circ}, 36.53^{\circ}$ and $59.93^{\circ}$ respectively along position 2 Theta.

Table 2: Chemical Compositions of RHA and OPC

\begin{tabular}{ccccccccccccc}
\hline Compounds & $\mathrm{SiO}_{2}$ & $\mathrm{Al}_{2} \mathrm{O}_{3}$ & $\mathrm{Fe}_{2} \mathrm{O}_{3}$ & $\mathrm{TiO}_{2}$ & $\mathrm{MgO}$ & $\mathrm{CaO}$ & $\mathrm{Na}_{2} \mathrm{O}$ & $\mathrm{K}_{2} \mathrm{O}$ & $\mathrm{P}_{2} \mathrm{O}_{5}$ & $\mathrm{MnO}$ & $\mathrm{SO}_{3}$ & LOI \\
\hline $\mathrm{RHA}(\%)$ & 86.99 & 2.55 & 0.34 & 0.13 & 0.78 & 0.43 & 0.86 & 0.69 & 0.11 & 0.08 & 1.45 & 0.61 \\
$\mathrm{OPC}(\%)$ & 19.63 & 5.12 & 5.33 & 0.12 & 4.24 & 56.43 & 0.96 & 1.08 & 0.19 & 0.08 & 3.17 & 0.79 \\
\hline
\end{tabular}

Table 3: Physical Properties of RHA and OPC

\begin{tabular}{|c|c|c|}
\hline Description & RHA & OPC \\
\hline Mean Particle Size $(\mu \mathrm{m})$ & 4.26 & 4.20 \\
\hline Blaine's Fineness (Specific Surface Area, m²/g) & 182.67 & 184.36 \\
\hline
\end{tabular}




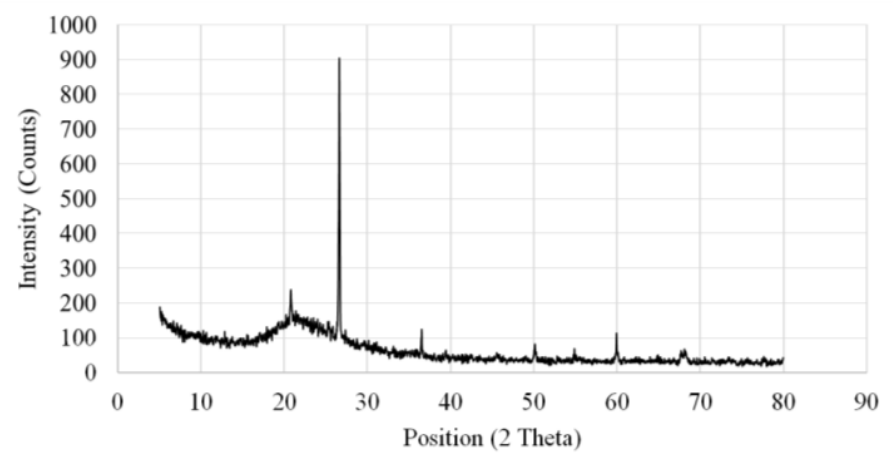

Figure 1: XRD Profile of Rice Husk Ash with Evidence of Amorphous Phases of $\mathrm{SiO}_{2}$

\subsection{Particle Size Distribution of RHA}

The particle size distribution of the RHA was done in accordance with [14] and the plot shown in Figure 2, reveals how the particles of the RHA are uniformly distributed. Due to the fine powdery nature of the RHA, less than $35 \%$ of its particles passed through the sieve size of $0.075 \mathrm{~mm}$, thus, placing it in the class of granular materials in accordance with the soil classification system of [15]. Particle size influences many properties of the particular material especially RHA and it is one of the valuable properties, which indicate the quality and performance of the RHA. According to [16], the mechanical experiments of RHA blended Portland cement concretes revealed that in addition to the pozzolanic reactivity of RHA, the particle size distribution of cement and RHA mixtures also exerted significant influences on the blending efficiency because the particles tended to fill every available void within the mix. This tends to contribute to the relative strength increase of the concrete incorporated with rice husk ash.

\subsection{Bulk Density of RHA of RHA}

Table 4 presents the bulk density of the rice husk ash as a lightweight material. According to [17], the bulk density depends on how densely packed the particles

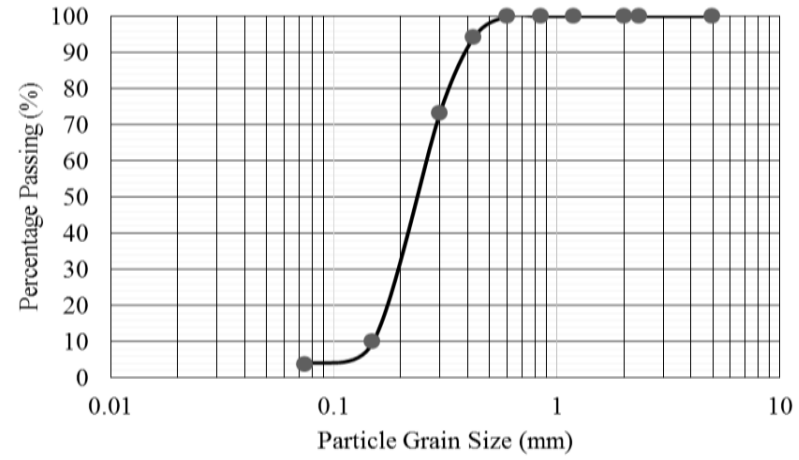

Figure 2: Particle Size Distribution of RHA Sample.

of the material are and consequently, on the size distribution and shape of the particles. The results of the bulk density test carried out on the RHA are tabulated in Table 3 and they show how densely packed the particles of the RHA are. The average uncompacted bulk density of the RHA is 338.15 $\mathrm{kg} / \mathrm{m}^{3}$, but due to the fact that the smaller particles of RHA usually rearrange themselves to fill the voids between the larger ones, this results in the higher value of $393.93 \mathrm{~kg} / \mathrm{m}^{3}$ noticeable for the compacted bulk density. With these values, it is evident that the RHA is a lightweight material. It was observed by [18], that the silica in pozzolana can only combine with calcium hydroxide when it is in a finely divided state; and pozzolana in this state has uniform particles which cannot be packed very closely together. This consequently results in low bulk density values.

\subsection{Relationship between Compressive Strength and Age}

Figure 3 shows a gradual increase in compressive strength of the LFC at age zero to age 28 days and then up to age 56 days for the binder/fine aggregate ratio of $1: 1.5$ and water/binder ratio of 0.4 , as the percentage replacement of cement by RHA increases.

Table 4: Bulk Density of RHA

\begin{tabular}{|c|c|c|c|}
\hline Description & & & \\
\hline \multirow{2}{*}{$\begin{array}{l}\text { Volume of Mould }\left(\mathrm{m}^{3}\right)=0.00173 \\
\text { Weight of Mould }(\mathrm{kg})=1.06\end{array}$} & & & \\
\hline & \multicolumn{2}{|c|}{ Tests } & \\
\hline & $1^{\text {st }}$ Test & $2^{\text {nd }}$ Test & Average Weight (kg) \\
\hline Weight of Compacted RHA Sample + Mould (kg) & 1.74 & 1.74 & 1.74 \\
\hline Weight of Un-compacted RHA Sample + Mould (kg) & 1.66 & 1.63 & 1.65 \\
\hline Weight of Compacted RHA Sample (kg) & 0.68 & 0.68 & 0.68 \\
\hline \multirow{3}{*}{$\begin{array}{l}\text { Weight of Un-compacted RHA Sample }(\mathrm{kg}) \\
\text { Average Compacted Bulk Density of Soil sample }\left(\mathrm{kg} / \mathrm{m}^{3}\right) \\
\text { Average Un-Compacted Bulk Density of Soil sample }\left(\mathrm{kg} / \mathrm{m}^{3}\right)\end{array}$} & 0.60 & 0.57 & 0.59 \\
\hline & \multicolumn{3}{|c|}{393.93} \\
\hline & \multicolumn{3}{|c|}{338.15} \\
\hline
\end{tabular}


From the Figure, the effect of the contributions of the RHA ash to the gain in compressive strength by the LFC can be seen. This indicates that the longer the time of curing of the LFC, the higher the strength gain, reaching up to $15.52 \mathrm{~N} / \mathrm{mm}^{2}$ at 28 days and 18.51 $\mathrm{N} / \mathrm{mm}^{2}$ at 56 days for binder/fine aggregate ratio of 1:1.5 and water/binder ratio of 0.4 at percentage cement replacement of $30 \%$.

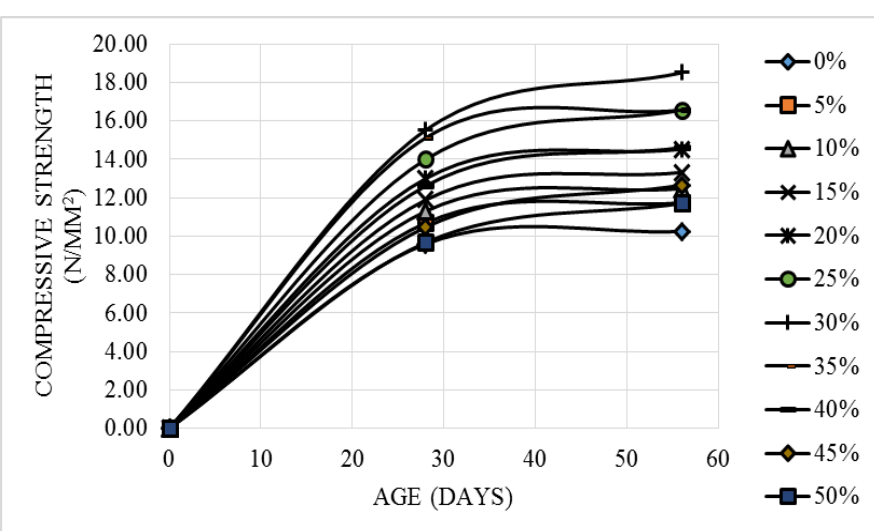

Figure 3: Relationship between Compressive Strength and Age at binder/fine aggregate Ratio of 1:1.5

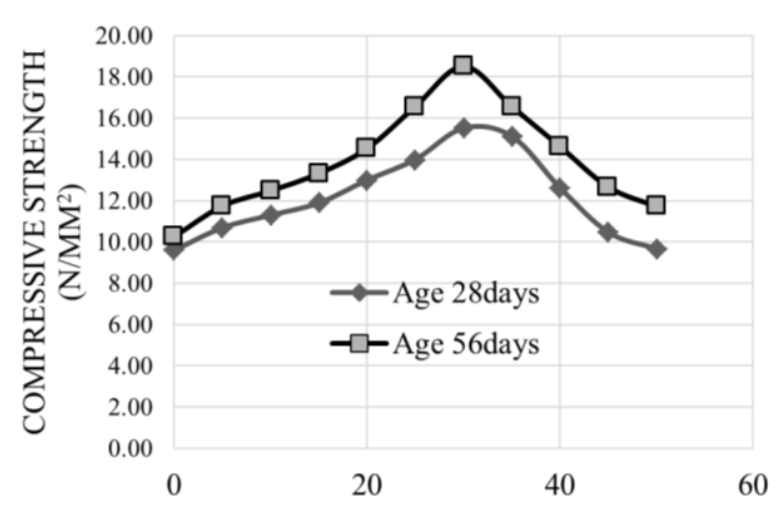

PERCENTAGE REPLACEMENT BY RHA (\%) Figure 4: Relationship between 28-Day and 56-Day Compressive Strength and Percentage Replacement with RHA at binder/fine aggregate Ratio of 1:1.5 and water/binder Ratio of 0.4

\subsection{Relationship between Compressive Strength of LFC at 28 and 56 Days}

Figure 4 shows the relationship between compressive strength and percentage replacement of cement RHA at age 28 and 56 days and at binder/fine aggregate ratios of 1:1.5 and water/binder ratio of 0.4 . The relationship reveals that the compressive strengths increase when cement is replaced by RHA up to $30 \%$ and starts to decrease from $35-50 \%$. This is due to the fact that when foam is introduced to the concrete, it not only creates air voids or pore spaces, but also increases the total quantity of water present inside the pore spaces within the concrete mass on a water/binder bases. According to [19], the alkalinity of the water increases to $\mathrm{pH} 13$ or even higher; and this enables the hydration of cement, during which tricalcium silicates, $\left(\mathrm{C}_{3} \mathrm{~S}\right)$ and dicalcium silicates $\left(\mathrm{C}_{2} \mathrm{~S}\right)$ react to form calcium silicate hydrates (C-S-H), which is largely responsible for strength development. At this point, lime $\mathrm{Ca}(\mathrm{OH})_{2}$, is thus liberated. It was also reported by [19] that high $\mathrm{pH}$ causes the silicate network of the RHA to break down into smaller units, which react with the $\mathrm{Ca}(\mathrm{OH})_{2}$ to form more C-S-H binder. The total effect of this is that the $\mathrm{Ca}(\mathrm{OH})_{2}$ in the concrete, which does not possess the strength forming properties of its own, is during the pozzolanic reaction, converted by the RHA to additional C-S-H binder, which enters the pore spaces. Also in line with the conclusion of [19], these reactions lead to a general densification of the cement matrix, which ultimately contributes to the increase in compressive strength of the foamed concrete up to $30 \%$ cement replacement by RHA. But between 35 - $50 \%$ replacement, the quantity of RHA now present within the concrete mass for both mix proportions, becomes higher than required, thus causing the pozzolanic reaction to drastically slow down and reduce the strength [19]. At this point, the excess $\mathrm{SiO}_{2}$ in the RHA leaches out and the RHA now acts just like an ordinary filler.

The incorporation of higher percentage of RHA after $30 \%$ in the mixture, makes the smaller grains of the RHA to fill up the voids within the concrete mass and with the gradual decrease in the pozzolanic reaction, results in the reduction of the compressive strength of the foamed concrete and this is in agreement with [20]. The $30 \%$ optimal level of cement replacement obtained agrees with the conclusion of [21], in their investigation of a high value of compressive strength of mortars for all content of water/binder ratios by using $30 \%$ as a replacement of part of cement. These results also confirm that the compressive strength of lightweight foamed concrete is mainly dependent on the binder/fine aggregate ratio, water/binder ratio, type and amount of foam, curing regime, type of sand and the particle size distribution of the sand and RHA.

\subsection{Contributions of RHA to the Strength of LFC at water/binder ratio of 0.4}

Table 5 shows the contributions of the RHA to the compressive strength at 28 and 56 days, when a comparison is made between the compressive 
strength of the LFC at cement replacement levels of 0 $\%$ and the LFC at cement replacement level of $30 \%$ for binder/fine aggregate ratio of 1:1.5. It was observed by [19] that the maximum compressive strength at cement replacement of $30 \%$ for binder/fine aggregate ratio of $1: 1.5$ and for lower water/binder ratio of 0.4 is due to the gradual occurrence of the pozzolanic reaction, which peaked at cement replacement of $30 \%$. The introduction of foam also causes an increase in the number of air voids created between the particles of the fine aggregates and these air voids take in more number of the smaller grains of both the RHA and cement.

It was also noted by [20] that the incorporation of higher percentage of RHA after $30 \%$ in the concrete mixture, makes the smaller grains of the RHA to fill up the voids within the concrete mass and results in the reduction of the compressive strength of the LFC. The $30 \%$ optimal level of cement replacement obtained agrees with the conclusion of [21], in their investigation of a high value of compressive strength of mortars for all content of water/binder ratios by using $30 \%$ as a replacement of part of cement.

\section{CONCLUSION}

The overall conclusions from this study are;

1. The Rice Husk Ash is a Class $\mathrm{N}$ pozzolanic material, which satisfies all the specifications of ASTM C618-12a (2012) with $\mathrm{SiO}_{2}, \mathrm{Al}_{2} \mathrm{O}_{3}$ and $\mathrm{Fe}_{2} \mathrm{O}_{3}$ having a minimum total sum of $70 \%$, LOI of a maximum of $10 \%$ and $\mathrm{SO}_{3}$ of a maximum of $4 \%$.

2. Rice Husk Ash has shown the capability of contributing up to $80 \%$ and above to the compressive strength of lightweight foamed concrete if partially added to replace cement.

3. The optimal replacement level of cement by rice husk ash is $30 \%$.

4. The mix proportion of 1:1.5 at water/binder ratio 0.4 is capable of producing a structural lightweight concrete with a compressive strength of $18.51 \mathrm{~N} / \mathrm{mm}^{2}$ at 28 days.

\section{REFERENCES}

[1] V. S. Deijk "Foam Concrete", Concrete July/August, 1991, pp. 49-54.

[2] P. Stroven, D. D. Bui and E. Sabuni "Ash of Vegetable Waste Used for Economic Production of Low to High Strength Hydraulic Binders", Fuel 78, pp.153159. (1999).

[3] N. Beningfield, R. Gaimster and P. Griffin "Investigation into the Air void Characteristics of Foamed Concrete", RMC Materials CEMEX UK Operations, United Kingdom, Proceedings of the International Conference on Use of Foamed Concrete in Construction ( $5^{\text {th }}$ July 2005), pp. 51-60. (2005).

[4] K. Brady, G. Watts and M. R. Jones "Specification for Foamed Concrete", Highway Agency and TRL Application Guide AG 39, PR/IS/40/01, TF 3/31. (2001).

[5] Y. L. Lee and Y. T. Hung "Exploitation of Solid Wastes in Foamed Concrete, Challenges Ahead in Use of Foamed Concrete in Construction", International Conference of University of Dundee, Scotland, UK Thomas Telford. (2005).

[6] Vitro Minerals, VCAS White Pozzolanas "Portland Cement and Pozzolanas", Journal on Technical Background for the Effective Use of VCAS Pozzolanas in Portland cement Concrete (October 2006), pp.1-7. (2006).

[7] K. Kishore "Foamed Cellular Light Weight Concrete", Concrete Engineering Research Papers, Civil Engineering Portal. (2012).

[8] American Society for Testing and Materials (2014) "Standard Test Method for Oxidation Characteristics of Extreme-Pressure Lubrication Oils" (ASTM D2893-04:). (2014).

[9] E. P. Kearsley and H. F. Mostert "Designing Mix Composition of Foamed Concrete with High Fly Ash Contents", In: Dhir, R. K., Newlands, M. D. and McCarthy, A. Editors Use of Foamed Concrete in Construction, London: Thomas Telford, pp. 89-96. (2005).

[10] BS EN 12390-3: "Testing Hardened ConcreteCompressive Strength of Test Specimens". (2009).

Table 5: Contributions of RHA to the Strength of LFC at water/binder Ratio of 0.4

\begin{tabular}{|c|c|c|c|c|c|}
\hline $\begin{array}{l}\text { No. of } \\
\text { Days }\end{array}$ & $\begin{array}{c}\text { Percentage } \\
\text { Replacement } \\
\text { by RHA (\%) }\end{array}$ & $\begin{array}{l}\text { water/binder } \\
\text { Ratio }\end{array}$ & $\begin{array}{l}\text { Mix Proportions (binder/fine } \\
\text { aggregate Ratio) }\end{array}$ & $\begin{array}{l}\text { Compressive } \\
\text { Strength } \\
\left(\mathrm{N} / \mathrm{mm}^{2}\right)\end{array}$ & $\begin{array}{l}\text { To Increase in } \\
\text { Compressive } \\
\text { Strength (\%) }\end{array}$ \\
\hline 28 & $\begin{array}{c}0 \\
30\end{array}$ & \multirow{3}{*}{0.4} & \multirow{3}{*}{ 1:1.5 } & $\begin{array}{c}9.59 \\
15.52\end{array}$ & 61.84 \\
\hline & & & & & \\
\hline 56 & $\begin{array}{c}0 \\
30\end{array}$ & & & $\begin{array}{l}10.25 \\
18.51\end{array}$ & 80.59 \\
\hline
\end{tabular}


[11] American Society for Testing and Materials "Standard Specification for Coal Fly Ash and Raw or Calcined Natural Pozzolan for Use in Concrete" (ASTM C618-12a). (2012).

[12] S. Wansom, S. Janjaturaphan and S. Sinthupinyo "Pozzolanic Activity of Rice Husk Ash: Comparison of Various Electrical Methods", Journal of Metals, Materials and Minerals, 19 (2), pp. 1-7. (2009).

[13] Q. Feng, H. Yamamichi, M. Shoya and S. Sugita "Study on the Pozzolanic Properties of Rice Husk Ash by Hydrochloric Acid Pretreatment", Cement and Concrete Research. 34 (3): pp. 521-526. (2004).

[14] British Standard European Norm "Testing Aggregates - Methods for Determination of Particle Size Distribution Sieves Tests", BS EN 933-1 (2012).

[15] American Society for Testing and Materials "Standard Practice for Classification of Soils and Soil-Aggregate Mixtures for Highway Construction Purposes" (ASTM D3282-93:2004). (2004).

[16] D. D. Bui, J. Hu and P. Stroeven "Particle Size Effect on the Strength of Rice Husk Ash Blended Gapgraded Portland Cement Concrete", Cement and Concrete Composites, 27 (3), pp. 357-366. (2005).

[17] British Standard European Norm "Tests for Mechanical and Physical Properties of Aggregates.
Determination of Loose Bulk Density and Voids", BS EN 1097-3 (1998).

[18] E. B. Oyetola and M. Abdullahi, M. "The Use of Rice Husk Ash in Low-Cost Sandcrete Block Production", Leonardo Electronic Journal of Practices and Technologies ISSN 1583-1078, Issue 8, pp. 58-70. (2006).

[19] Vitro Minerals, VCAS White Pozzolanas "Portland Cement and Pozzolanas", Journal on Technical Background for the Effective Use of VCAS Pozzolanas in Portland cement Concrete, pp. 1-7. (October 2006).

[20] S. P. Narayanan, V. Kalaikumar, M. F. Yusoff, A. Anwar, M. F. Haron and M. N. Alias "Properties of Rice Husk Ash (RHA and MIRHA) Mortars" Research Journal of Applied Sciences, Engineering and Technology 7 (18), pp. 3872-3882, 2014 ISSN: 2040-7459; e-ISSN: 2040-7467 (C) Maxwell Scientific Organization. (2014).

[21] K. Ganesan, K. Rajagopal, and K. Thangavel "Rice Husk Ash Blended Cement: Assessment of Optimal Level of Replacement for Strength and Permeability Properties of Concrete", Construction and Building Materials, 22 (8), pp. 1675-1683. (2008). 